\title{
TOLERANSI ANTARUMAT BERAGAMA DALAM MENINGKATKAN PERSATUAN DAN KESATUAN BANGSA
}

\author{
Shalma Adeesya Al' Rahma \\ IIK Strada Indonesia \\ shalmadsyalr@gmail.com
}

\begin{abstract}
Abstrak
Bangsa Indonesia memiliki kekayaan budaya nasional yang bermacam suku, adat istiadat, ras, gender dan budaya yang harus kita menjunjung tinggi toleransi antar umat beragama dengan semangat persatuan dan kesatuan. Penelitian ini menggunakan penelitian kualitatif dengan pendekatan studi kasus. Teknik pengumpulan data menggunakan observasi, wawancara, dokumentasi. Teknik analisis data adalah reduksi data, display data dan verifikasi data. Hasil penelitian menyebutkan bahwa nilainilai dasar yang menjadi landasan terbentuknya toleransi antar umat beragama Islam, Buddha dan Kristen di masyarakat secara normatif terdapat pada nilai agama dan nilai budaya. Sedangkan, secara empirik nilai-nilai terbentuknya toleransi antar umat beragama di masyarakat meliputi (1) nilai kemanusiaan; (2) nilai nasionalisme; (3) nilai historis,; (4) nilai keteladanan tokoh masyarakat; dan (5) nilai kesabaran. Selain itu, Bentuk toleransi antar umat beragama Islam, Buddha dan Kristen di masyarakat dapat ditinjau secara toleransi agama dan toleransi sosial. Bentuk toleransi sosial berupa kerjasama antara umat Islam, Buddha dan Kristen masyarakat terdiri atas gotong-royong, kegiatan 17 Agustus dan Kegiatan Ibu-Ibu PKK.
\end{abstract}

Kata Kunci: Toleransi;Umat beragama Islam, Budha dan Kristen; Persatuan Bangsa.

\section{Latar Belakang}

Indonesia dikenal sebagai bangsa yang terdiri dari masyarakat yang majemuk kaya akan keberagaman, seiring dengan perkembangan zaman yang ditandai dengan banyaknya etnis, agama, suku, budaya, adat-istiadat dan bahasa. Keberagaman yang dimiliki oleh bangsa Indonesia merupakan suatu nilai positif yang memerlukan perhatian khusus agar hal tersebut mampu menjadi sumber kekuatan dan ciri khas bangsa Indonesia. Masyarakat Indonesia bersifat multi etnis, multi religius dan multi ideologis. Kemajemukan tersebut menunjukkan adanya berbagai unsur yang saling berinteraksi. Berbagai unsur dalam bidangbidang kehidupan masyarakat merupakan benih-benih yang dapat memperkaya khasanah budaya untuk membangun bangsa yang kuat. Kemajemukan bangsa Indonesia termasuk dalam hal agama adalah merupakan kekayaan budaya nasional yang dapat menjadi kebanggaan. Keberagaman dalam beragama merupakan sebuah kenyataan yang tidak dapat dihindari. Sehingga setiap umat beragama mempunyai kewajiban untuk mengakui sekaligus menghormati agama lain tanpa membeda-bedakan. Menteri Koordinator Bidang Pembangunan Manusia dan Kebudayaan (Menko PMK) Muhadjir Effendy menjelaskan, pentingnya menerapkan prinsip-prinsip kemerdekaan dan kebebasan untuk menumbuhkan 
sikap toleransi, saling menghormati antar pemeluk agama yang berbeda dengan latar belakang sosial-budaya yang berbeda. Menurutnya hal tersebut dapat meningkatkan rasa persatuan dan kesatuan yang kuat sebagai modal membangun bangsa Indonesia kedepannya. "Semboyan Bhineka Tunggal Ika memiliki makna sesuai dengan keberagaman Indonesia yang tidak hanya bersuku-suku, ber ras-ras, dsn berbudaya tetapi kita punya makna yang jauh lebih luas bahwa kita memang ditakdirkan sebagai pribadi yang berbeda satu sama lain namun tetap satu tujuan."

Toleransi sangat berpengaruh dalam kehidupan bangsa indonesia. Kita tidak boleh lupa akan sejarah ketika pada zaman penjajahan, semua rakyat bersatu berasal ras, suku dan agama yang berbeda dengan tujuan dan semangat yang sama untuk memerdekakan bangsa dan negara indonesia. Dengan semangat persatuan dan kesatuan inilah menumbuhkan rasa toleransi sehingga menjadi pendorong kemerdekaan negara indonesia. Jadi dengan adanya toleransi dapat menjadikan keadaan negara yang damai tanpa ada permasalahan ras, suku dan agama maupun budaya. Sejalan dengan pendapat KH. Abdurrahman Wahid yaitu rukun berdampinga "Bukankah demikian menjadi jelas bagi kita bahwa menerima perbedaan pendapat dan asal muasal bukanlah tanda kelemahan, melainkan menunjukan kekuatan "dan" tidak penting apapun agamamu atau sukumu. Kalau kamu bisa melakukan sesuatu yang baik untuk semua orang, orang tidak pernah menanyakan apa agamamu”.

\section{Kasus Masalah}

Merdeka.com - Ketua Umum Partai Persatuan Pembangunan (PPP), Djan

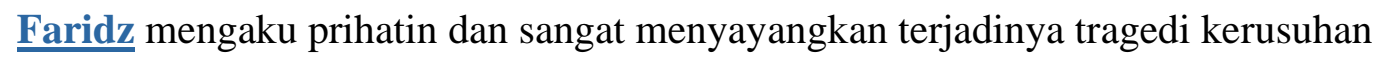
pembakaran rumah dan tempat ibadah etnis tertentu di Tanjungbalai, Sumatera Utara, Sabtu (30/7).

"Peristiwa ini disebabkan masyarakat telah kehilangan kultur toleransi antar umat beragama," kata Djan Faridz dikutip dari Antara, Minggu (31/7).

Tragedi kerusuhan yang awalnya dipicu oleh protes seorang warga etnis tertentu atas berkumandangnya azan di masjid yang berada di depan rumahnya menyebabkan ketersinggungan dan kemarahan umat Islam yang berujung terjadi peristiwa pembakaran rumah dan vihara. Menurut dia, Islam yang ada di Nusantara telah memiliki kultur panggilan azan dikumandangkan lewat pengeras suara. Azan bagi umat Islam bukan sekedar panggilan salat tapi juga syiar suci atas nama Allah, sangat menggugah batin umat Islam. Oleh karena itu, menggugatnya atau melarangnya berarti mengusik batin keyakinan umat Islam. "Jangan ada orang yang memancing di air keruh menyangkut soal SARA. Karena dampak kerusakan sosialnya amat parah, baik secara fisik maupun secara psikologis," katanya mengingatkan. 
Dia pun berharap, adanya saling memahami kultur dan tradisi agama masing-masing guna mencegah terjadinya kesalahpahaman dan kesewenang-wenangan antar umat beragama.

"Setiap agama memiliki tata cara ibadah dengan kultur yang berbeda. Di sinilah letak pemahaman untuk toleransi antar umat beragama. Jika ini dipahami maka peristiwa di Tanjungbalai tidak akan terjadi. Kerusuhan di Tanjungbalai jika tidak disikapi dengan serius, hati-hati dan cepat, baik oleh aparat, pemerintah dan tokoh agama, maka akan bisa meluas menjadi konflik ras dan gejolak kebencian atas etnis tertentu. Ini justru resonansinya akan jauh lebih berbahaya bagi keutuhan NKRI," jelas Djan. Sebagai Ketua Umum Partai Islam, PPP mengimbau untuk menjaga keutuhan dan persatuan dalam masyarakat, maka diperlukan sikap saling menghormati dan saling menghargai, sehingga gesekan-gesekan yang dapat menimbulkan pertikaian dapat dihindari. "Masyarakat juga dituntut untuk saling menjaga hak dan kewajiban di antara mereka antara yang satu dengan yang lainnya," katanya. Sebagaimana diamanatkan dalam UUD 1945 pasal 29 ayat 2 disebutkan bahwa 'Negara menjamin kemerdekaan tiap-tiap penduduk untuk memeluk agamanya masing-masing dan untuk beribadat menurut agamanya dan kepercayaannya itu'. Djan mencontohkan, bahwa toleransi dan penghormatan pada kultur agama sangat besar di Indonesia dibandingkan dengan negara-negara lain, di mana negara memberikan hari libur nasional bagi hari-hari besar agama-agama yang ada di Indonesia. "Oleh karenanya, kita sebagai warga negara sudah sepatutnya menjunjung tinggi sikap saling toleransi antar umat beragama dan saling menghormati antar hak dan kewajiban termasuk kultur dan tradisi agama yang ada di antara kita demi keutuhan negara. Adanya dalil adagium toleransi dalam Islam yakni, Lakum dinukum waliyadin. Bagimu agamamu dan bagi kami agama kami," ucapnya. Djan juga mengajak umat Islam agar tidak cepat terprovokasi, reaktif serta anarkis yang melampaui kewenangan aparat. "Marilah kita tampilkan wajah Islam yang ramah, santun dan penuh kasih sayang sebagaimana contoh yang ditunjukkan Rasulullah SAW dalam kehidupan beragama dan bernegara di Madinah, karena Islam Rahmatan lil alamin," ujar Djan. [rnd] 


\section{Tinjauan Pustaka}

Pada intinya Toleransi berarti sifat dan sikap menghargai. Sifat dan sikap menghargai harus ditunjukkan oleh siapapun terhadap bentuk pluralitas yang ada di Indonesia. Sebab toleransi merupakan sikap yang paling sederhana, akan tetapi mempunyai dampak yang positif bagi integritas bangsa pada umumnya dan kerukunan bermasyarakat pada khususnya. Tidak adanya sikap toleransi dapat memicu konflik yang tidak diharapkan. Pelaksanaan sikap toleransi ini harus didasari dengan sikap kelapangan dada terhadap orang lain dengan memperhatikan prinsip-prinsip yang dipegang sendiri, yakni tanpa mengorbankan prinsip-prinsip tersebut (Daud Ali, 1989:83). Jelas bahwa toleransi terjadi dan berlaku karena terdapat perbedaan prinsip, dan menghormati perbedaan atau prinsip orang lain tanpa mengorbankan prinsip sendiri.

Di dalam memaknai toleransi ini terdapat dua penafsiran tentang konsep tersebut. Pertama, penafsiran negatif yang menyatakan bahwa toleransi itu cukup mensyaratkan adanya sikap membiarkan dan tidak menyakiti orang atau kelompok lain baik yang berbeda maupun sama. Sedangkan yang kedua adalah penafsiran positif yaitu menyatakan bahwa toleransi tidak hanya sekedar seperti pertama (penafsiran negatif) tetapi harus adanya bantuan dan dukungan terhadap keberadaan orang lain atau kelompok lain.

Dalam toleransi terdapat butir-butir refleksi, yaitu :

a) Kedamaian adalah tujuan, toleransi adalah metode nya.

b) Toleransi adalah terbuka dan reseptif pada indahnya perbedaan.

c) Toleransi menghargai individu dan perbedaanya, menghapus topeng dan ketegangan yang disebabkan oleh ketidak pedulian. Menyediakan kesempatan untuk menemukan dan menghapus stigma yang disebabkan oleh kebangsaan, agama, dan apa yang diwariskan.

d) Toleransi adalah saling menghargai satu sama lain melalui pengertian.

e) Benih dari intoleransi adalah ketakutan dan ketidakpedulian.

f) Benih dari toleransi adalah cinta, disiram dengan kasih dan pemeliharaan.

g) Jika tidak cinta tidak ada toleransi.

h) Yang tahu menghargai kebaikan dalam diri orang lain dan situasi memiliki toleransi.

i) Toleransi juga berarti kemampuan menghadapi situasi sulit.

j) Toleransi terhadap ketidaknyamanan hidup dengan membiarkan berlalu, ringan, membiarkan orang lain ringan.

k) Melalui pengertian dan keterbukaan pikiran orang yang toleran memperlakukan orang lain secara berbeda, dan menunjukkan toleransinya. Akhirnya, hubungan yang berkembang. 


\section{Pembahasan}

masyarakat Indonesia tergolong masyarakat yang majemuk karena terdapat beberapa agama yang dianut oleh yaitu agama Islam, agama Buddha dan agama Kristen. Dengan berkembangnya dua agama maka akan mempengaruhi interaksi dan hubungan sosial antar pemeluk agama. Dalam kesehariannya tidak hanya bergaul dengan sesama agama melainkan juga berkumpul dengan masyarakat yang selain Islam. Agar tercipta suasana kekerabatan yang kondusif maka harus diimbangi dengan sikap saling manghormati dan menghargai keunikan masing-masing.

Agama memiliki peranan dominan dalam menciptakan masyarakat berbudaya. Agama dapat dikatakan memainkan peran yang baik apabila mampu memberikan kepada pemelukpemeluknya suatu gambaran nilai-nilai yang luhur dari eksistensi dan esensi jagat raya. Sebaliknya, agama dikatakan memegang peran ke arah yang negatif apabila mengurung pemeluknya dalam alam pikiran yang sempit sehingga memunculkan konflik agama. Racun diskriminasi, ejekan, dan saling membenci dapat menciptakan disintegrasi bangsa. Untuk mengantisipasi terjadinya konflik agama maka semua umat yang beragama harus bersatu dalam persahabatan dengan kehendak baik guna mencapai harapan semua orang yang cinta damai dalam membangun masyarakat yang serasi, aman dan tentram.

Kehidupan yang harmonis tidak terlepas dari ketersediaan tempat dan waktu untuk umat beragama melaksanakan ibadah sesuai dengan keyakinannya secara aman. Karena ibadah merupakan sarana penghubung antara Sang Pencipta dengan makhluknya.

Hasil penelitian menunjukkan bahwa nilai-nilai dasar yang menjadi landasan terbentuknya toleransi antar umat beragama Islam, Buddha dan Kristen di Masyarakat yang hidup berdampingan secara rukun, damai dan saling menghargai satusama lain. Masyarakat umumnya mengedepankan sikap toleransi antar umat beragama yang dapat menerima kehadiran agama lain dengan segala kegiatannya. Sehingga masyarakatnya mewujudkan toleransi tersebut sampai saat sekarang ini. Bahkan untuk memberikan suasana yang baik, penerimaan itu diimbangi dengan terjadinya pergaulan antar umat beragama.

Menurut W.J.S.Poerwadarminto, (2003, p.184) dalam "Kamus Umum Bahasa Indonesia" toleransi adalah sikap/sifat menenggang berupa menghargai serta memperbolehkan suatu pendirian, pendapat, pandangan, kepercayaan maupun yang lainnya yang berbeda dengan pendirian sendiri. Istilah Tolerance (toleransi) adalah istilah modern, baik dari segi nama maupun kandungannya. (Anis Malik Thoha, 2005, p.212). Sedangkan Toleransi berasal dari bahasa Latin, yaitu Tolerantia, yang artinya kelonggaran, kelembutan 
hati, keringanan dan kesabaran. Dari sini dapat dipahami bahwa toleransi merupakan sikap untuk memberikan hak sepenuhnya kepada orang lain agar menyampaikan pendapatnya, sekalipun pendapatnya salah dan berbeda. (Zuhairi Misrawi, 2007, p.161). Sikap toleransi diwujudkan dalam bentuk interaksi dan kerja sama antara berbagai golongan. Sejalan dengan pendapat menurut Wahono (2001, p.26) mengatakan bahwa masing-masing agama seharusnya berusaha keras untuk mengisi pemahaman dan kegiatannya dengan hal-hal yang mendorong hubungan saling bekerjasama untuk semua orang. Secara normatif nilai-nilai dasar yang menjadi landasan terbentuknya toleransi antar umat beragama adalah sebagai berikut:

Pertama adalah nilai agama yang bersumber dari ajaran yang terdapat pada masingmasing agama baik itu Islam, Buddha maupun Kristen yang menjelaskan tentang pentingnya sikap toleransi antar umat beragama. Konsep Tolerasi menurut ajaran agama islam bahwa konteks toleransi antar-umat beragama, Islam memiliki konsep yang jelas terdapat pada surat Al Kafirun ayat 6 yang berbunyi "Lakum Diinukum Waliyaddin”. "Tidak ada paksaan dalam agama", "Bagi kalian agama kalian, dan bagi kami agama kami”. Jadi apa yang diajarkan dalam agama Islam, toleransi bukan saja terhadap sesama manusia, tetapi juga terhadap alam semesta, binatang, dan lingkungan hidup. Toleransi merupakan suatu kata dari "damai", "selamat" dan "menyerahkan diri” yang selalu disampaikan bahwa agam islam itu agama rahmatan lil 'alamin yang artinya (agama yang mengayomi seluruh alam semesta) dan Allah mempertegas dalam firman-Nya QS. Al- Anbiya: 107 “Dan tidaklah engkau (Muhammad) diutus ke muka bumi ini kecuali sebagai rahmat bagi seluruh alam”. Ini berarti bahwa Islam bukan untuk menghapus semua agama yang sudah ada. Islam menawarkan dialog dan toleransi dalam bentuk saling menghormati.

Begitu juga dalam Agama Budha mengajarkan konsep toleransi dalam agama Budha menyadari keberadaan keyakinan dan agama lain serta berusaha hidup rukun, damai, dan harmonis dengan keyakinan lain tersebut melalui toleransinya yang besar terhadap ajaran lain tersebut. Toleransi dalam agama budha ada istilah "Semoga Semua Makhluk Hidup Berbahagia" perlu adanya toleransi untuk membuat itu semua terwujud. Jika tidak ada toleransi, itu tak terwujud. Toleransi bisa diartikan bahwa sesuatu tidak bersinggungan. Selain itu dalam ajaran agama Budha kita mengenal yang namanya "Sila" kemudian dalam agama Buddha kita mengenal juga "Maitri Karuna" yaitu memberikan kebahagiaan kepada orang, 
atau menginginkan orang lain bahagia, dan tidak membiarkan orang lain merasakan penderitaan, dengan itu saja kita sudah mengembangkan sikap toleransi.

Sedangkan menurut penuturan Tokoh Agama Kristen mengatakan dalam ajaran Agama Kristen yang berlandaskan pada hukum kasih yang berbunyi: (1) kasihilah Tuhan Allahmu dengan segenap hatimu dan segenap jiwamu, (2) kasihilah sesamamu seperti dirimu sendiri. Bahkan terhadap musuh pun harus saling mengasihi. Karena dengan mengembangkan sikap saling mengasihi maka akan menjadi anak-anak bapamu yang disurga. Dalam Al Kitab Kristen Imamat 19-18 berkata “Janganlah engkau menuntut balas, dan janganlah menaruh dendam terhadap orang-orang sebangsamu, melainkan kasihilah sesamamu manusia seperti dirimu sendiri; Akulah TUHAN”. Intinya sesama manusia saling mengasihi dan selalu mendukung setiap perbedaan agama.

Jadi dapat dikatakan bahwa konsep Toleransi antar umat beragama Islam, Buddha maupun Kristen sudah terjalin sejak dahulu pada masyarakat yang mana agama masingmasing mewajibkan umatnya untuk hidup rukun, saling mengenal, saling mendukung, menghormati, hidup rukun, kerjasama, damai dan harmonis dalam menjalani kehidupan bersama-sama. Sejalan dengan pendapat H.S, Seno dalam Rina Rehayati, 2009, p.58) Toleransi merupakan kerukunan umat beragama yang dengan dasar dan titik tolak yang berbeda-beda, saling memikul untuk mencapat satu tujuan tertentu. Sikap toleransi diwujudkan dalam bentuk interaksi dan kerja sama antara berbagai golongan. Begitu juga menurut Wahono (2001, p.26) mengatakan bahwa masing-masing agama seharusnya berusaha keras untuk mengisi pemahaman dan kegiatannya dengan hal-hal yang mendorong hubungan saling bekerjasama untuk semua orang.

Kedua Nilai Budaya yang lahir dari kebiasaan-kebiasaan yang dilakukan oleh sekelompok orang dan telah menjadi tradisi di lingkungan masyarakat tertentu. Misalkan kebiasaan gotong-royong, guyub rukun dan Seni Kuda Lumping yang turut mewarnai kehidupan masyarakat. Masyarakat tetap mempertahankan budaya gotong-royong, guyub rukun, Kuda Lumping dan Karawitan sebagai wujud kebutuhan bersama dan sekaligus nilai yang membangun sikap kebersamaan di tengah-tengah perbedaan agama. Nilai budaya gotong-royong tidak memandang manusia berdasarkan agama, ras dan pangkat, melainkan memiliki kedudukan yang setara. Sedangkan, apabila ditinjau secara empirik berarti nilai-nilai yang menjadi landasan terbentuknya toleransi antar umat beragama. 
Tali persaudaraan yang sejati tercermin dalam kehidupan masyarakat Sejalan dengan pendapat ST Munadjat D, (2003, p.30) mengatakan "Dalam kehidupan masyarakat yang serba majemuk, berbangsa dan bernegara, berbagai perbedaan yang ada seperti dalam suku, agama, ras atau antar golongan, merupakan realita yang harus didayagunakan untuk memajukan negara dan bangsa Indonesia, menuju cita-cita nasional kita adalah masyarakat adil dan makmur berdasarkan Pancasila dan UUD 1945 dalam Negara Kesatuan Republik Indonesia”.

Persatuan berasal dari kata satu yang berarti utuh atau tidak terpecah-belah. Menurut Syarbaini (2010, p.43) menyatakan bahwa "Persatuan mengandung arti bersatunya macam-macam corak yang beraneka ragam menjadi satu kebulatan yang utuh dan serasi”. Dalam hal ini persatuan Indonesia adalah persatuan yang mendiami wilayah Indonesia. Oleh sebab itu, Persatuan dan kesatuan merupakan keseragaman serta bersatunya berbagai macam perbedaan, suku, agama, ras dan budaya yang berbeda disatu wilayah untuk bersama-sama mewujudkan tujuan nasional. Sehingga Semua umat Islam, umat Buddha dan Kristen memiliki kesempatan untuk melakukan kegiatan keagamaan dalam rangka meningkatkan iman dan takwa terhadap Sang Pencipta dan sekaligus sebagai sarana memperlancar interaksi sosial hubungan kemasyarakatan.

\section{Kesimpulan}

Berdasarkan hasil penelitian dan pembahasan maka dapat disimpulkan bahwa konsep Toleransi antar umat beragama Islam, Buddha maupun Kristen sudah terjalin sejak dahulu pada masyarakat yang mana agama masing-masing mewajibkan umatnya untuk hidup rukun, saling mengenal, saling mendukung, menghormati, kerjasama, damai dan harmonis dalam menjalani kehidupan bersama-sama. Oleh sebab itu, nilai-nilai dasar yang menjadi landasan terbentuknya toleransi antar umat beragama Islam, Buddha dan Kristen secara normatif terdapat pada nilai agama dan nilai budaya. Pertama nilai agama yang bersumber dari ajaran yang terdapat pada masing-masing agama baik itu Islam, Buddha maupun Kristen yang menjelaskan tentang pentingnya sikap toleransi antar umat beragama. Kedua nilai Budaya yang lahir dari kebiasaan-kebiasaan yang dilakukan oleh masyarakat tetap mempertahankan budaya gotong-royong, guyub rukun dan Seni Kuda Lumping sebagai wujud kebutuhan bersama dan sekaligus nilai yang membangun sikap kebersamaan di tengah-tengah perbedaan agama. Sedangkan, secara empirik nilai-nilai yang mendasari terbentuknya toleransi antar umat beragama di Masyarakat meliputi (1) nilai kemanusiaan; (2) nilai nasionalisme; (3) nilai historis,; (4) nilai keteladanan tokoh masyarakat; dan (5) nilai kesabaran.

Bentuk toleransi antar umat beragama Islam, Buddha dan Kristen di masyarakat dapat ditinjau secara toleransi agama dan toleransi sosial. Bentuk toleransi agama bagi umat Islam tercermin dari kegiatan-kegiatan keagamaan yang rutin diadakan seperti Tahlil, Wirid, Muslimat NU, Khataman, dan Pengajian. Adapun bentuk toleransi bagi umat agama Buddha melalui kegiatan seperti Puja Bakti, Hari Raya Waisak, Asaddha, dan Ulang tahun 
Vihara dan kegiatan keagamaan yang wajib maupun kesenian seperti Karawitan yang dilaksanakan. Sedangkan, bentuk toleransi agama bagi umat Kristen melalui kegiatan keagamaan seperti kebaktian keluarga, kebaktian Anak-anak dan ibadah tiap hari Minggu di GPI (Gereja Penyebaran Injil). Sementara toleransi sosial berupa kegiatan bersama atau kerjasama yang melibatkan antara umat Islam, Buddha dan Kristen adalah gotong-royong, perayaan hari besar agama.

\section{Daftar Pustaka}

A. Ali, Mohammad Daud. 1986. Islam Untuk Disiplin Ilmu Hukum, Sosial dan Politik. Jakarta: CV.Wirabuana.

B. Anis, M, Thoha. 2005. Tren Pluralisme Agama. Jakarta : Prespektif.

A’la, A. (2009). Agama Tanpa Penganut: Memudarnya Nilai-Nilai Moralitas dan Signifikansi Pengembangan Teologi Kritis. Yogyakarta: Kanisius.

Sodik, M. A., \& Nzilibili, S. M. M. (2017). The Role Of Health Promotion And Family Support With Attitude Of Couples Childbearing Age In Following Family Planning Program In Health. Journal of Global Research in Public Health, 2(2), 82-89.

Oktoriani, E. N., Sutrisno, J., Mayasari, E., \& Sodik, M. A. (2018). Analysis of medical record complete flexibility to complete claims of health BPJS RS Baptis Kota Batu. Journal of Global Research in Public Health, 3(1), 46-53.

Sodik, M. A. (2018, September). Analysis of Improved Attitude of Youth in HIV/AIDS Prevention through the Provision of Health Education with Peer Education. In The 2nd Joint International Conferences (Vol. 2, No. 2, pp. 495-502).

Sodik, M. A., \& Setyani, A. T. (2018). Effect of Smoking For Teens Against Behavior and Social Interaction.

Sodik, M. A., Suprapto, S. I., \& Pangesti, D. (2013). Faktor-Faktor Yang Berhubungan Dengan Pelaksanaan Pelayanan Prima Pegawai Di Rsui Orpeha Tulungagung. STRADA Jurnal Ilmiah Kesehatan, 2(1), 2432.

Setyani, A. T., \& Sodik, M. A. (2018). Pengaruh Merokok Bagi Remaja Terhadap Perilaku dan Pergaulan Seharihari.

Attoriq, S., \& Sodik, M. A. (2018). Pencegahan Dan Pengendalian Infeksi Terkait Pelayanan Kesehatan Di Lahan Praktik.

Siyoto, S., \& Sodik, M. A. (2015). Dasar metodologi penelitian. Literasi Media Publishing.

Sodik, M. A. (2018). Merokok \& Bahayanya. 
